\title{
Redaksioneel
}

\section{Riglyne vir boek-, proefskrif- en verhandelingbespreking}

Medewerkers wat behulpsaam is met boek-, proefskrif- en verhandelingbesprekings word versoek om dit in te rig volgens die volgende kwantitatiewe en kwalitatiewe aspekte:

\section{KWANTTTATIEWE ASPEKTE}

1. Uit hoeveel dele bestaan die boek?

2. Wat is die lengte van die hoofstukke of hoofstuk-onderafdelings?

3. Watter onderafdeling of hoofstuk is die langste?

4. Hoeveel opdragte bevat die boek (indien dit 'teorie-en-inoefening'gedeeltes sou bevat)?

5. Hoeveel opdragte bied 'n uitdaging, en hoeveel is niksseggend of triviaal?

6. Hoeveel aanhangsels is daar? Hoeveel indekse is daar (outeurs- en sakeregisters)?

7. Hoeveel tabelle en/of illustrasies het die boek?

8. Hoeveel items is in die bibliografie opgeneem? Hoeveel van hierdie items het hulle oorsprong in Suid-Afrika en hoeveel is van die buiteland afkomstig?

9. Wat is die tydspan wat die bibliografie dek? Hoeveel resente werke (die afgelope dekade) is ingesluit?

10. Hoeveel direkte aanhalings is in die boek opgeneem: 'n bevredigende aantal, of teveel?

11. Watter outeurs is die meeste aangehaal?

12. Hoeveel artikels is uit vaktydskrifte aangehaal: nasionaal en internasionaal?

13. Hoeveel paragrawe word in die boek aangetref wat te lank is of moeilik verstaanbaar is?

14. Hoeveel navorsingsprojekte word genoem?

15. Hoeveel sleutelkonsepte word ingesluit?

16. Watter tegniese terme word gebruik?

17. Hoeveel konsepte bly onverduidelik?

- Hierdie is 'n verwerking van 'n vertaalde ekserp van 'n artikel wat verskyn het in die tydskrif Notes on Linguistics 52 (1991), 39-40. Die artikel is op sy beurt 'n vertaling wat gemaak is deur Dwight Day, met die titel Guidelines for writing book reviews. Dic oorspronklike artikel het in Ciência e Cultura 37/1 van 1985 vcrskyn. Dic outeur, Francisco Gomes dc Matos, is 'n professor in Lettere cn Psigologic aan die Federale Universiteit van Pernambuco in Brasilië. Hy het vir sy nagraadse studente voorstelle aan die hand gedoen vir 'n oorsiglys ten opsigte van die evaluering van 'n akademiese bock met die oog op die skryf van 'n resensie. Hy en sy grocp het die lys saamgestel. 


\section{KWALTTATIEWE ASPEKTE}

1. Boei die openingsparagraaf die leser?

2. Wat is die outeur se tese of sentrale idee?

3. Wat is die outeur se doel? Waarom het hy die boek geskryf? Wat is die verlangde effek?

4. Watters idees lê ten grondslag van die outeur se tese?

5. Watter idees dien die outeur se doel?

6. Watter tipes faktiese getuienis word aangebied (bv wetenskaplik, histories, statisties)?

7. Berus die outeur se redevoering op kundiges se sienings, en word aanhalings strategies aangewend?

8. Word die voorbeelde generies of spesifiek gebruik?

9. Word die boek gekenmerk deur ' $n$ logies-koherente en konsistente organisering?

10. Watter organisatoriese patroon volg die boek? Word dit ingedeel in onderafdelings, hoofstukke, 'teorie-en-inoefening'-gedeeltes, of word probleme gestel vir oplossing en bespreking?

11. Is die trant van die outeur te formeel of te informeel, te persoonlik, of geskik vir die beoogde leser? Waarom?

12. Wat is die sterk- en swakpunte van die outeur se argument(e)? Voorsien hy moontlike besware?

13. Is die konsepte en terminologie presies en korrek?

14. Is die bibliografie doelmatig of ornamenteel deur die skrywer aangewend?

15. Is die boek ingerig volgens 'n relevante tegniese ortografiese standaard (soos byvoorbeeld ' $n$ algemeen-erkende ortografie en literatuurverwysingstelsel)?

16. Wie sal daarby baat vind om die werk te lees? Hoekom?

17. Hoe vergelyk die werk met soortgelyke werke?

18. Hoe samehangend is die hoofstukke?

19. Hoe balanseer die deugde en foute in die boek mekaar uit? (Wees grootmoedig: $U$ kon die outeur van die boek gewees het.)

20. Is die konklusie korrelerend met die vraagstelling/hipotese en spruit dit voort uit die argumentering; is dit oortuigend, sterk en die moeite werd om te onthou? 